\title{
A new species of Trichomycterus (Siluriformes: Trichomycteridae) from lagoa Feia drainage, southeastern Brazil
}

\author{
Sergio M. Q. Lima ${ }^{1}$, Henrique Lazzarotto ${ }^{2}$ and Wilson J. E. M. Costa ${ }^{3}$
}

Trichomycterus caipora, new species, is described from rio Macabu basin, lagoa Feia drainage, serra de Macaé, southeastern Brazil. The new species is distinguished from its congeners from southern and southeastern Brazil by the combination of: the presence of nine pectoral-fin rays, caudal fin emarginated and high number of opercular and interorpecular odontodes. Ecological notes are presented and putative phylogenetic relationships and characters shared with congeners are discussed.

Trichomycterus caipora, espécie nova, é descrita para a bacia do rio Macabu, drenagem da lagoa Feia, serra de Macaé, sudeste do Brasil. A nova espécie distingue-se dos demais Trichomycterus do sul e sudeste do Brasil pela combinação: da presença de nove raios na nadadeira peitoral, nadadeira caudal emarginada e elevado número de odontódeos operculares e interoperculares. Dados ecológicos são apresentados e as supostas relações filogenéticas e caracteres compartilhados com espécies do gênero são discutidos.

Key words: Catfishes, Trichomycterus caipora, Freshwater fishes, Atlantic Forest, Rio de Janeiro State, rio Macabu basin.

\section{Introduction}

The family Trichomycteridae is a monophyletic assemblage of small freshwater catfishes with 41 genera and approximately 200 species, distributed from Patagonia to Costa Rica, in both sides of Andes (de Pinna \& Wosiacki, 2003; de Pinna, 1998). Trichomycterid genera are usually constituted of few species, and are all defined by synapomorphies (de Pinna \& Wosiacki, 2003), except for Trichomycterus Valenciennes, which is apparently non-monophyletic (de Pinna, 1989, 1992). With more than a hundred nominal species, the genus comprises most of the trichomycterids. It is also the only genus represented in both sides of Andes, including the Andean altiplano (de Pinna \& Wosiacki, 2003).

Despite the large number of species and taxonomic problems, many species of Trichomycterus have been described recently (e.g., Fernández \& Schaefer, 2005; Sarmento-Soares et al., 2005; Wosiacki, 2005; Wosiacki \& Oyakawa, 2005; Alencar \& Costa, 2006; Fernández \& Osinaga, 2006; Castellanos-Morales, 2007; Fernández \& Chuquihuamaní, 2007; Fernández \& Miranda, 2007; Castellanos-Morales, 2008; Wosiacki \& de Pinna, 2008a,b) and many more are waiting to be described, since the majority of species have limited distribution, displaying a high level of endemism (Eigenmann, 1918; Costa, 1992; Bockmann \& Sazima, 2004). Since just a few species are known to occur outside the watersheds from which they were described [e. g., Trichomycterus brasiliensis Lütken and T. zonatus (Eigenmann)] and these wide-range species may constitute species-complexes (Barbosa \& Costa, 2003; Bockmann \& Sazima, 2004), the typical approach for osteological and morphological comparison is to focus only on the 49 southern and southeastern Brazilian species of Trichomycterus [T.albinotatus Costa, T. alternatus (Eigenmann), T. auroguttatus Costa, T. brasiliensis Lüetken, T. candidus

\footnotetext{
${ }^{1}$ Programa de Pós-Graduação em Genética, Laboratório de Biodiversidade Molecular, Instituto de Biologia, Departamento de Genética, Universidade Federal do Rio de Janeiro, Cidade Universitária, CCS, Bloco A, 21941-470 Rio de Janeiro, RJ, Brazil. smaialima@gmail.com ${ }^{2}$ PROAMA - Programa de Avaliação de Mananciais da Costa Verde, ONG Conhecer para Conservar, Rua Aníbal de Mendonça, 66/103, 22410-050 Rio de Janeiro, RJ, Brazil. kiko_lazzarotto@yahoo.com.br

${ }^{3}$ Laboratório de Ictiologia Geral e Aplicada, Departamento de Zoologia, Universidade Federal do Rio de Janeiro, Caixa Postal 68049, $21944-$ 970 Rio de Janeiro, RJ, Brazil. wcosta@acd.ufrj.br
} 
(Miranda-Ribeiro), T. castroi de Pinna, T. caudofasciatus Alencar \& Costa, T. concolor Costa, T. crassicaudatus Wosiacki \& de Pinna, T. cubataonis Bizerril, T. davisi (Haseman), T. diabolus Bockmann, Casatti \& de Pinna, T. florensis (Miranda-Ribeiro), T. giganteus Lima \& Costa, $T$. goeldii Boulenger, T. guaraquessaba Wosiacki, T. igobi Wosiacki \& de Pinna, T. iheringi (Eigenmann), T. immaculatus Eigenmann \& Eigenmann, T. itacambirussu Triques \& Vono, T. itacarambiensis Trajano \& de Pinna, T. itatiaye (MirandaRibeiro), T. jacupiranga Wosiacki \& Oyakawa, T. jequitinhonhae Triques \& Vono, T. landinga Triques \& Vono, T. longibarbatus Costa, T. maracaya Bockmann \& Sazima, $T$. mboycy Wosiacki \& Garavello, T. mimonha Costa, $T$. mirissumba Costa, T. naipi Wosiacki \& Garavello, T. nigricans Valenciennes, T. pantherinus Alencar \& Costa, T. paolence (Eigenmann), T. papilliferus Wosiacki \& Garavello, T. paquequerensis (Miranda-Ribeiro), T. pauciradiatus Alencar \& Costa, T. plumbeus Wosiacki \& Garavello, T. postchi Barbosa \& Costa, T. reinhardti (Eigenmann), T. stawiarski (MirandaRibeiro), T. taroba Wosiacki \& Garavello, T. travassosi (Miranda-Ribeiro), T. trefauti Wosiacki, T. triguttatus (Eigenmann), T. tupinamba Wosiacki \& Garavello, T. variegatus Costa, T. vermiculatus (Eigenmann), T. zonatus (Eigenmann)] all from rio Paraná, rio São Francisco and coastal Atlantic basins, disregarding northern and Andean species .

A new species of Trichomycterus from rio Macabu basin, an isolated river basin draining into a lake (lagoa Feia), in northern Rio de Janeiro State, southeastern Brazil, is herein described.

\section{Material and Methods}

Measurements and counts follow Costa (1992). Measurements are presented as percentages of standard length (SL), except for subunits of head, which are presented as percentage of head length. Counts of procurrent caudal-fin rays, vertebrae, branchiostegal rays, teeth and odontodes were made only in cleared and stained specimens (c\&s) prepared according to Taylor \& Van Dyke (1985). Additional comparative material is listed below. Morphological data of T. castroi, T. concolor, T. crassicaudatus, T. cubataonis, T. davisi, T. diabolus, T. guaraquessaba, T. igobi, T. iheringi, T. itacambirussu, T. itacarambiensis, T. jacupiranga, T. jequitinhonhae, T. landinga, T. maracaya, T. mboycy, T. naipi, T. nigricans, T. paolence, T. papilliferus, T. paquequerensis, T. plumbeus, T. stawiarski, T. taroba, T. trefauti, T. triguttatus, T. tupinamba, and T. vermiculatus were found in the original descriptions of each species. Tissue samples from two paratypes were deposited in Laboratório de Biodiversidade Molecular (LBDM). Abbreviations for institutions are: MCP, Museu de Ciências e Tecnologia da Pontifícia Universidade Católica do Rio Grande do Sul, Porto Alegre; MNRJ, Museu
Nacional, Rio de Janeiro; MZUSP, Museu de Zoologia da Universidade de São Paulo, São Paulo; and UFRJ, Universidade Federal do Rio de Janeiro, Rio de Janeiro.

\section{Trichomycterus caipora, new species}

Figs. 1-2

Holotype. UFRJ 6583, 114.6 mm SL; Brazil, Estado do Rio de Janeiro: Município de Conceição de Macabu, lagoa Feia drainage, rio Macabu basin, rio Macabu upstream the confluence of rio Carocango and rio Macabu, 22 ${ }^{\circ} 04$ '51.8'S 41 '58'55.3"W, 28 June 2006, S. Lima, H. Jabor \& H. Lazzarotto.

Paratypes. UFRJ 7247, 12, 69.6-116.2 mm SL; UFRJ 7614, 3 (c\&s), 69.1-75.0 mm SL; MNRJ 31924, 77.9-87.6 mm SL; all collected with holotype. UFRJ 7257, 69.0-69.9mm SL; Brazil, Estado do Rio de Janeiro, Município de Conceição de Macabu, rio Macabu basin, rio Carocango, upstream Cachoeira da Amorosa, tributary to rio Macabu, same collectors and date as holotype.

Diagnosis. Similar to T. giganteus, T. immaculatus and $T$. nigricans and distinguished from the remaining congeners from southern and southeastern Brazil by having nine pectoral-fin rays (vs. eight or fewer) and more odontodes (interopercular 59-70, vs. 19-52, opercular 23-30, vs. 10-20). Easily distinguished from T. giganteus, T. immaculatus, and T. nigricans by having the caudal fin emarginate ( $v s$. truncate). It further differs from $T$. giganteus by having shorter nasal and maxillary barbels (nasal reaching posterior margin of eye $v s$. reaching pectoral-fin base; maxillary reaching anterior portion of interopercular patch of odontodes vs. reaching anterior third of pectoral fin), and from T. immaculatus and T. nigricans by the presence of four irregular longitudinal rows of rounded blotches on trunk (vs. homogeneous colour pattern).

Description. Morphometric data for holotype and paratypes given in Table 1. Body moderately deep, subcylindrical on anterior portion, compressed on caudal peduncle. Dorsal profile slightly convex between snout and end of dorsal-fin base, approximately straight from this point to base of caudal fin. Ventral profile convex between lower jaw and end of anal-fin base, straight on caudal peduncle.

Head depressed, longer than wider, subtriangular in dorsal view. Eye at middle of head, orbital rim not free. Skin covering eye thin and translucent. Snout blunt. Mouth subventral. Lower lip with conspicuous lateral fleshy lobes. Maxilla slightly longer than premaxilla. Teeth conical. Tip of nasal barbel reaching posterior margin of eye. Tip of maxillary and rictal barbels reaching anterior portion of interopercular patch of odontodes. Base of maxillary and rictal barbels, lips and ventral portion of head covered by papillae. Branchial membranes thick, united to isthmus anteriorly by thin flap of skin. Seven branchiostegal rays. Interopercular odontodes 65-70; opercular patch of odontodes wide, with 26-28 odontodes; 


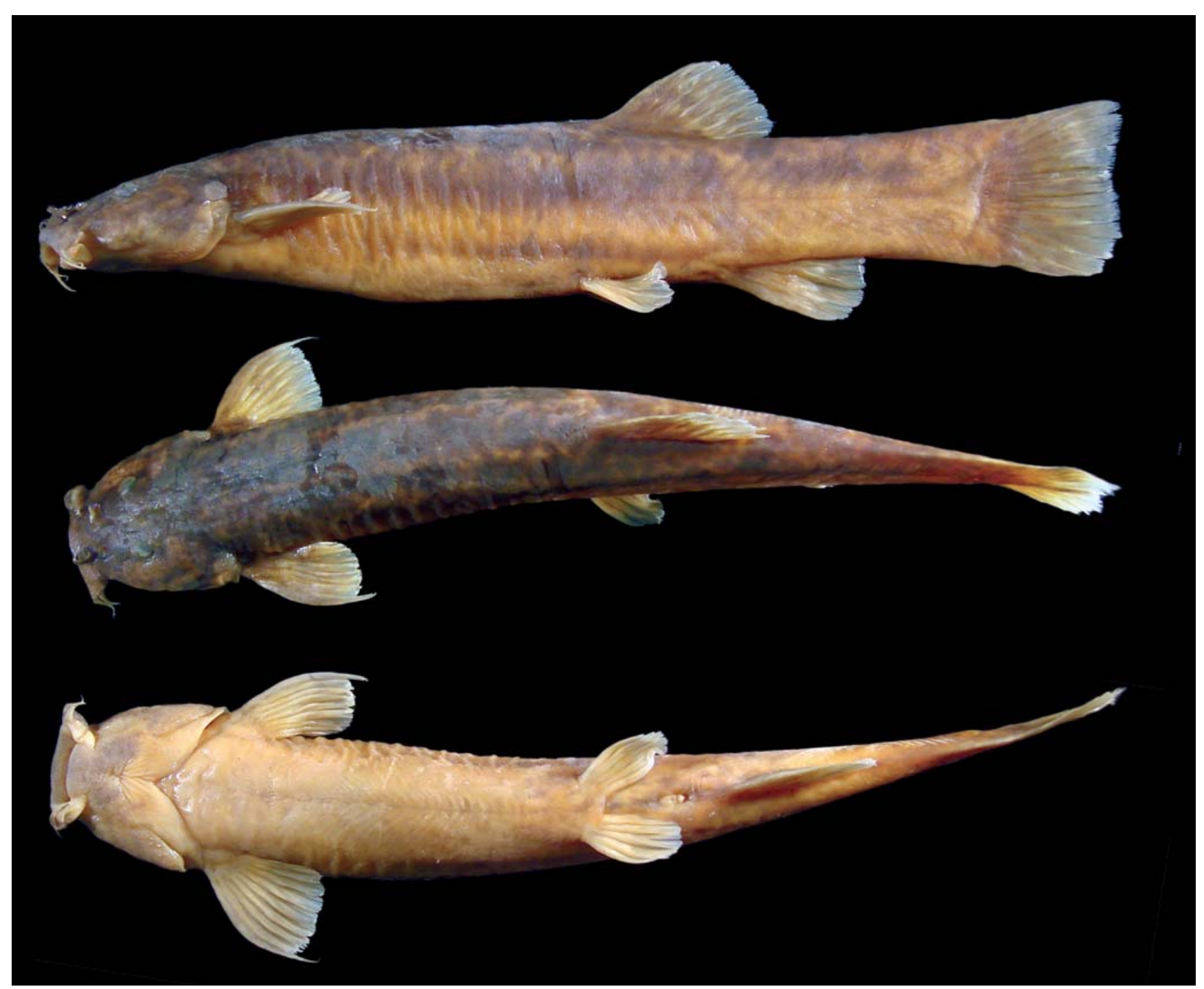

Fig. 1. Trichomycterus caipora, lateral, dorsal and ventral views. Holotype, UFRJ 6583; 114.6 mm SL. Brazil, Rio de Janeiro, Conceição de Macabu, rio Macabu upstream the confluence of rio Carocango and rio Macabu.

odontodes conical, opercular odontodes wider than interopercular odontodes; opercular odontodes arranged vertically. Medial margin of autopalatine slightly concave; posterior process of autopalatine slightly shorter than autopalatine without posterior process. Lacrimal about one fourth supraorbital length; supraorbital rod-like. Metapterygoid small, without distinct processes. Anterodorsal surface of hyomandibula with weak concavity (Fig. 3). Third supraorbital pore fused (9 in 16 specimens), sometimes paired with each pore closer to symmetrical pore than to orbit. Anterior section of infraorbital canal present.

Pectoral-fin rays i,8. Pectoral fin somewhat triangular, lateral and posterior edges slightly convex. First pectoral-fin ray terminating as long filament, about $20-40 \%$ of pectoral-fin length. Pelvic fin about $2 / 3$ of anal fin length, tip not reaching anal fin or covering urogenital pore, tip at vertical through base of first branched dorsal-fin ray; pelvic-fin bases separated by interspace. Dorsal and anal fins approximately triangular. Dorsal-fin origin at vertical between centrum of $17^{\text {th }}$ and $18^{\text {th }}$ vertebra. Anal-fin origin posterior to vertical through dorsal-fin base, and through centrum of $23^{\text {rd }}$ or $24^{\text {th }}$ vertebra. Caudal fin emarginate. Dorsal-fin rays vii,5-6; anal-fin rays $\mathrm{v}, 5$; pelvic-fin rays $i, 4$; principal caudal-fin rays $6+7$, dorsal procurrent rays 12-16, ventral procurrent rays 11-15. Free vertebrae 35-36; precaudal vertebrae 12; caudal vertebrae 23-24; pleural ribs 12 . Upper hypural plates separated, dorsal plate as wide as ventral plate.

Coloration. Side of body orangish yellow, dorsal half yellowish brown, forming rounded blotches on trunk arranged in four irregular longitudinal rows: one along dorsal region, one along dorsolateral region (both in vertical from opercular patch 


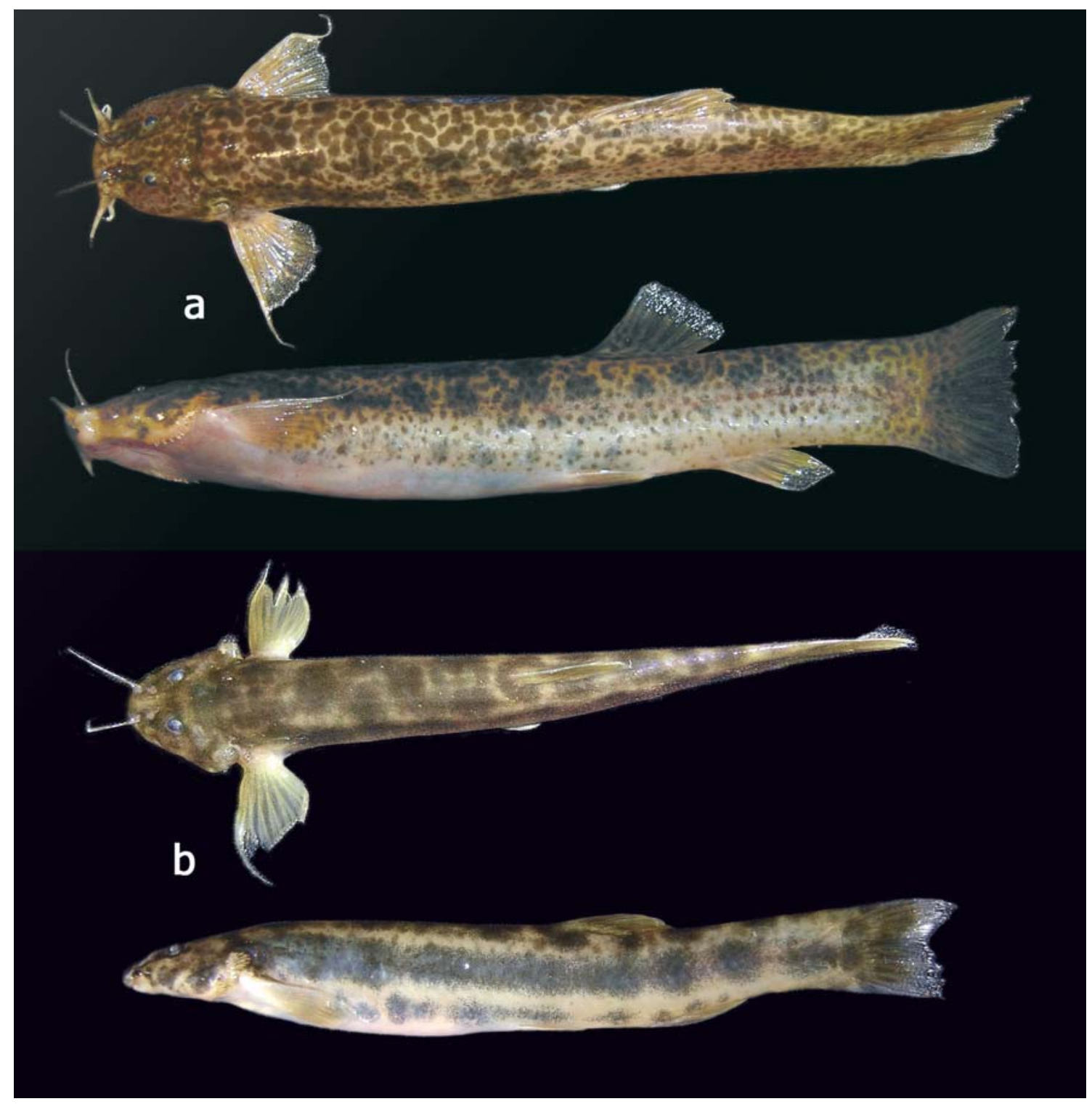

Fig. 2. Trichomycterus caipora immediately after preservation, showing phenotypic color variation, paratypes, UFRJ 7247 ; a, 116.2 mm SL ; b, 100.4 mm SL. Brazil: Estado do Rio de Janeiro: Conceição de Macabu.

of odontodes to caudal peduncle), one along midlateral region (from opercular patch of odontodes to caudal peduncle), all rows with chromatophores present both in superficial and deep layer of integument, and one along ventrolateral region (from behind pectoral fin to posterior margin of anal-fin base), with chromatophores restricted to inner layer of integument, and faint brown dots below lateral midline, venter yellowish white. Some specimens show dorsal and dorsolateral rows coalescent, forming single dark band on dorsal portion of body and head. Midlateral blotches sometimes coalesce forming well-defined or interrupted stripe (Fig. 2). Head orangish yellow, with chromatophores concentrated in the supraorbital and preopercular regions. Opercular and interopercular patches of odontodes light yellow; nasal barbel dark grey, maxillary and rictal barbels light grey. Iris yellow. Dorsal fin pale yellow with orangish brown spots on basal half, hyaline with brown dots on distal half. Caudal fin pale orangish brown with small dark brown spots, distal fourth hyaline. Pectoral and anal fins yellow with brown spots on proximal region. Pectoral-fin filament white. Pelvic fin pale yellow. Fins yellowish hyaline. Juvenile specimens with lighter homogeneous grayish pattern.

Etymology. From the Tupi, kaa pora (forest dweller), a forest dwelling creature of the Tupi mythology, with orange hair and a protector of the wildlife; an allusion to the fact that the new species is endemic to the Atlantic Rain Forest and possesses orangish yellow head. A noun in apposition. 
Table 1. Morphometric data of holotype and eleven paratypes of Trichomycterus caipora, from rio Macabu basin, Rio de Janeiro State, southeastern Brazil.

\begin{tabular}{lccccc}
\hline \multicolumn{7}{c}{ Holotype } & Min & Max & Mean & SD \\
\hline Standard length (mm) & 114.6 & 70.3 & 116.2 & & \\
Head length (mm) & 22.0 & 13.2 & 22.7 & & \\
\multicolumn{5}{c}{ Percents of } & standard length \\
Body depth & 17.9 & 15.8 & 17.9 & 16.9 & 0.7 \\
Caudal peduncle depth & 13.1 & 11.9 & 13.3 & 12.6 & 0.5 \\
Body width & 11.5 & 9.6 & 11.9 & 10.8 & 0.8 \\
Caudal peduncle width & 4.1 & 3.9 & 4.7 & 4.3 & 0.3 \\
Caudal peduncle length & 17.2 & 16.8 & 19.3 & 18.0 & 0.7 \\
Dorsal-fin base length & 12.2 & 10.8 & 12.2 & 11.4 & 0.5 \\
Anal-fin base length & 7.9 & 7.9 & 9.1 & 8.3 & 0.4 \\
Pelvic-fin length & 9.6 & 9.6 & 11.1 & 10.5 & 0.5 \\
Distance between & 1.5 & 0.9 & 1.5 & 1.1 & 0.2 \\
pelvic-fin bases & 12.9 & 12.9 & 15.6 & 14.2 & 0.9 \\
Pectoral-fin length & 61.0 & 59.9 & 63.7 & 61.5 & 1.1 \\
Predorsal length & 57.6 & 52.0 & 59.0 & 54.7 & 2.0 \\
Prepelvic length & 19.2 & 18.8 & 21.0 & 19.8 & 0.6 \\
Head length & Percents of head length & & \\
\multicolumn{7}{c}{ Head depth } & 59.1 & 57.3 & 65.9 & 60.7 & 2.3 \\
Head width & 87.7 & 82.7 & 96.2 & 89.0 & 3.4 \\
Interorbital width & 30.0 & 26.8 & 30.9 & 28.7 & 1.2 \\
Preorbital length & 46.4 & 42.3 & 48.9 & 45.1 & 2.3 \\
Eye diameter & 13.2 & 11.0 & 13.6 & 12.7 & 0.8 \\
\hline
\end{tabular}

Distribution. Trichomycterus caipora is only known from the type locality in the mountain streams of the rio Macabu basin, lagoa Feia drainage, serra de Macaé, northern Rio de Janeiro State, southeastern Brazil (Fig. 4). The new species can be found in several sites in the upper and middle reaches of the rio Macabu and its tributary streams.

Ecological notes. Rio Macabu basin encompasses an area of approximately $1,076 \mathrm{~km}^{2}$. Rio Macabu flows for about 120 $\mathrm{km}$ until it reaches lagoa Feia, an isolated lagoon in northern Rio de Janeiro State (Bizerril \& Primo, 2001). Its headwaters are located in serra de Macaé mountain range, at about 1,500 $\mathrm{m}$ above sea level, in areas partially covered with secondary Atlantic forest. The impact of human activities is visible along the entire course of rio Macabu. On the mountain slopes the main visible impacts are the presence of several buildings on the river banks, and also the deforestation for several purposes, such as agriculture and cattle raising.

Trichomycterus caipora was collected in clear, fast flowing streams and small rivers, with substrate composed mainly by rocks, gravel and coarse sand, in altitudes between 80 and $210 \mathrm{~m}$. Since no sampling was performed above this altitude, it is possible that $T$. caipora possesses a more extent longitudinal distribution. The original Atlantic forest vegetation is rare along the river banks; marginal vegetation, when present, was composed mainly by grass from adjacent pastures. Specimens were collected on the main channel of streams, in sites ranging from about $6 \mathrm{~m}$ to $15 \mathrm{~m}$ stream width, in depths of about $50 \mathrm{~cm}$, on substrate composed by varied size rocks, in spots with medium to fast water current.

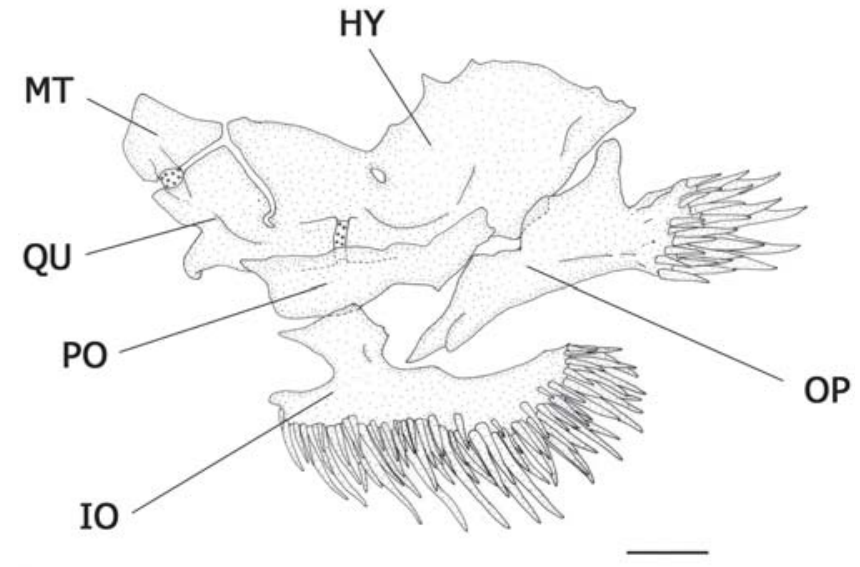

Fig. 3. Left suspensorium and opercular series of Trichomycterus caipora, UFRJ 7614, 69. $1 \mathrm{~mm}$ SL. Lateral view. Abbreviations : HY, hyomandibula ; IO, interoperculo ; MT, metapterygoid ; OP, opercle; PO, preopercle; QU, quadrate. Scale bar $=1 \mathrm{~mm}$.

Trichomycterus caipora seems to be nocturnal species. Only five juvenile specimens were captured in daylight, whereas 16 specimens were easily collected at dawn and night time. Underwater observations during daytime did not detect active individuals of Trichomycterus caipora. Only one individual was seen hiding under plant debris and rocks, in a shallow area of a pool just downstream from Cachoeira Amorosa, a $15 \mathrm{~m}$ high waterfall. Furthermore, three specimens of T. aff. zonatus were caught at this period always in sand beds, while 17 specimens were captured during daylight, when they were swimming active or buried in sand. This could suggest diel and microhabitat segregation between these congeneric species.

Other species collected with Trichomycterus caipora were Neoplecostomus microps (Steindachner), Ancistrus multispinnis (Regan), and Characidium sp. Furthermore, individuals of Geophagus brasiliensis (Quoy \& Gaimard) and Astyanax sp. were also observed.

\section{Discussion}

Although the relationships among large clades within the family Trichomycteridae are relatively well understood (de Pinna, 1998), the relationships among the Trichomycterinae, at the species-level are scarce and not based on strictly phylogenetic criteria (Costa, 1992; de Pinna, 1992; Barbosa \& Costa, 2003; Bockmann \& Sazima, 2004; Bockmann et al., 2004; Wosiacki \& de Pinna, 2008a,b). Besides the enormous specific diversity of Trichomycterus, the non-monophyletic nature of the Trichomycterinae (de Pinna, 1989) makes it difficult to establish well defined outgroups and, consequently, consistent polarities and unequivocal intrageneric synapomorphies (de Pinna, 1992; Bockmann \& Sazima, 2004). However some features shared 


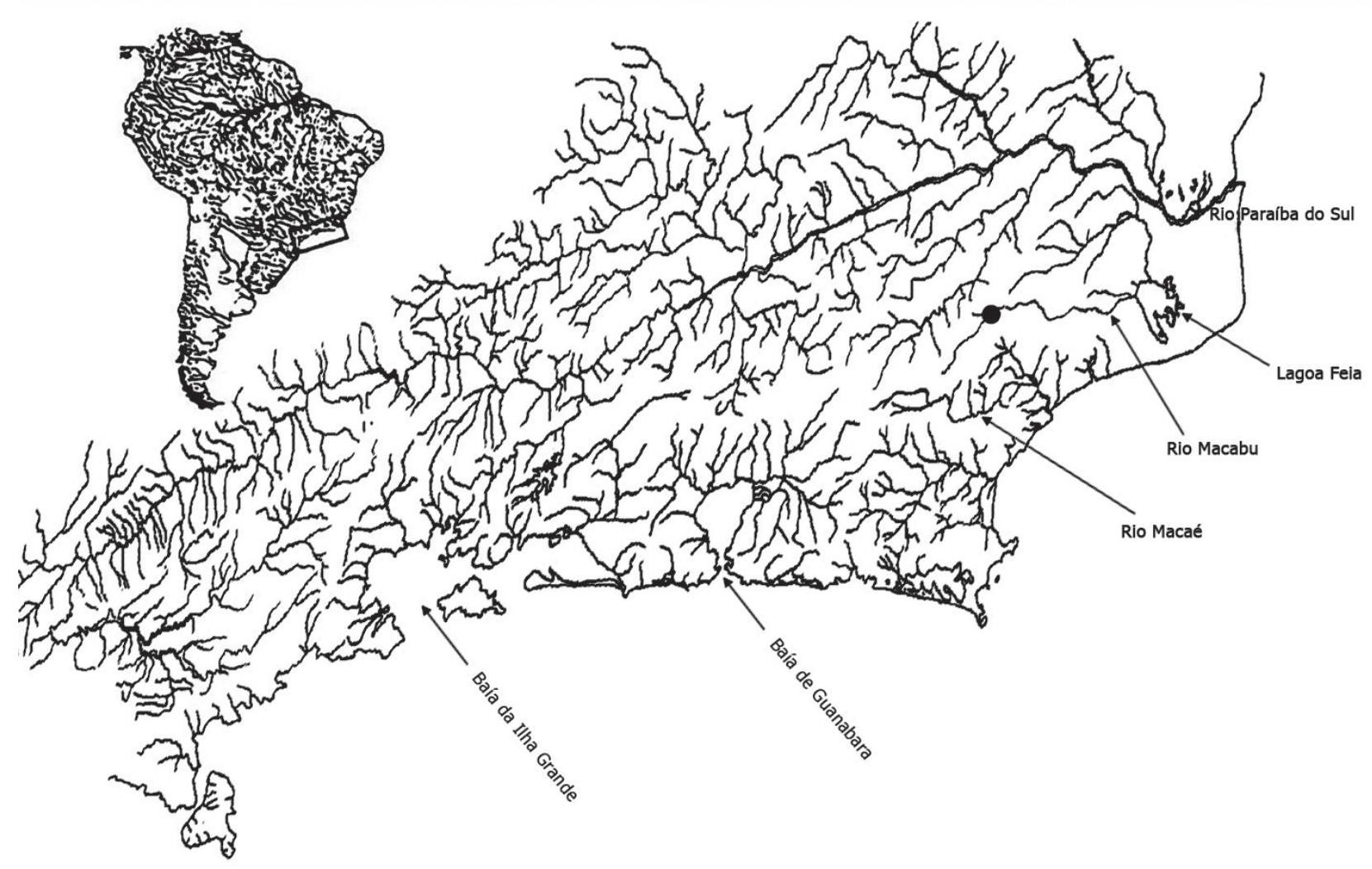

Fig. 4. Map of southeastern Brazil showing geographic distribution of Trichomycterus caipora. Symbol represents more than one sampling locality.

by Trichomycterus caipora and other Trichomycterus species, as well as their putative relationships can be discussed. Trichomycterus caipora could be closely related to the type species of the genus, T. nigricans, and to T. immaculatus and $T$. giganteus based on the presence of nine pectoral-fin rays (i+8) and more odontodes (interopercular 59-70, vs. 1952, opercular 23-30, vs. 10-20). Numerous opercular odontodes can be considered as a derived condition among the Trichomycterinae because opercular odontodes are absent in Copionodon de Pinna, and occurs in small number in Trichogenes longipinnis Britski \& Ortega (6-12), the phylogenetically basal trichomycterids (de Pinna, 1998), and in small number in most species of Trichomycterus and in other trichomycterids. Within the Trichomycterinae, Hatcheria macraei (Girard) has 11-12, Bullockia maldonadoi (Eigenmann) 13-14 and the other Trichomycterus species usually have 8-20 opercular odontodes.

Trichomycterus caipora also shares with $T$. giganteus a broad stripe along the trunk, a feature that is absent in $T$. nigricans and T. immaculatus. Trichomycterus caipora usually presents the third supraorbital pore fused, as in $T$. giganteus and T. nigricans (Arratia, 1998), and distinct from T. immaculatus, which has the third supraorbital paired. A fused third supraorbital is also present in T. jacupiranga, which is distinguished from $T$. caipora by having only eight pectoral-fin rays (Wosiacki \& Oyakawa, 2005).

The color pattern in Trichomycterus caipora, composed by blotches on trunk arranged in four longitudinal rows is present in many other Trichomycterinae species (Bockmann \& Sazima, 2004). In T. caipora the blotches sometimes coalesce forming well-defined [e. g., T. giganteus, T. maracaya, T. pauciradiatus, and T. variegatus] or interrupted stripe [e. g., T. albinotatus, T. alternatus, T. caudofasciatus, $T$. maracaya, and T. variegatus].

Among the described species of Trichomycterus from southern and southeastern Brazil, an emarginated caudal fin occurs only in T. florensis, T. paquequerensis (MirandaRibeiro, 1943) and in juveniles of T. crassicaudatus (Wosiacki $\&$ de Pinna, 2008b). However, T. caipora can be distinguished from $T$. florensis and $T$. paquequerensis by having a color pattern composed of four irregular longitudinal rows of rounded blotches on trunk ( $v s$. transversal dark bars and homogeneous colour pattern, respectively). Trichomycterus caipora and all other species of Trichomycterus could be easily distinguished from $T$. crassicaudatus by the latter species having a forked caudal fin in adults and the deepest caudal peduncle within the Trichomycteridae (Wosiacki \& de Pinna, 2008b).

Although not diagnosed by any autapomorphy, the combination of characters mentioned herein could easily diag- 
nose the new species. The possible close relationship with the type species of the genus, T. nigricans, could indicate that $T$. caipora would continue to be a Trichomycterus species, even if the genus becomes divided into many genera (de Pinna \& Wosiacki, 2003)

Comparative material examined. Copionodontinae: Copionodon sp., MZUSP 48962, 8 (2 c\&s). Trichogeninae: Trichogenes longipinnis, UFRJ 0861, 3, UFRJ 0682, 2 (c\&s). Trichomycterinae: Bullockia maldonadoi, MZUSP 36958, 2 (1 c\&s); Hatcheria macraei, MZUSP 35687, 2 (1 c\&s); Trichomycterus albinotatus, UFRJ 4657, 11, UFRJ 5628, 3 (c\&s); T. alternatus, UFRJ 080, 6, UFRJ 556, 2 (c\&s); T. auroguttatus, UFRJ 4101, 4, UFRJ 4558, 2 (c\&s); T. brasiliensis, UFRJ 4833, 5, UFRJ 4834, 3 (c\&s), $T$. candidus, UFRJ 4926, 31, UFRJ 4928, 5 (c\&s); T. caudofasciatus, UFRJ 5655, 10 paratypes, UFRJ 5656, 5 paratypes (c\&s); $T$. florensis, UFRJ 595, 9, UFRJ 646, 1 (c\&s); T. giganteus, UFRJ 599, holotype, MCP 35028, 4 paratypes, UFRJ 5730, 10 paratypes, UFRJ 5732, 2 paratypes (c\&s); T. goeldii, UFRJ 1063, 3, UFRJ 5434, 2 (c\&s); T. immaculatus, UFRJ 3593, 1, UFRJ 082, 2, UFRJ 557, 1 (c\&s), UFRJ 420, 6; T. itatiayae, UFRJ 4833, 5, UFRJ 4834, 3 (c\&s), UFRJ 4923, 2; T. longibarbatus, UFRJ 629, 1 paratype, UFRJ 3368, 5, UFRJ 5674, 3 (c\&s); T. mimonha, UFRJ 641, 7 paratypes, UFRJ 5209, 1 (c\&s), T. mirissumba, UFRJ 642, 3 paratypes, UFRJ 4730, 5 (c\&s); T. pantherinus, UFRJ 6001, holotype, MCP 35029, 6 paratypes, UFRJ 5660, 6 paratypes (c\&s); T. pauciradiatus, UFRJ 5807, 22, UFRJ 5808, 6 paratypes (c\&s);T. potschi, UFRJ 4727, 11 paratypes, UFRJ 4728, 5 (c\&s); T. reinhardti, UFRJ 1144, 3, UFRJ 4553, 3 (c\&s); T. travassosi, UFRJ 5670, 3, UFRJ 4554, 3 (c\&s), UFRJ 5671, 8; T. variegatus, UFRJ 584, 9, UFRJ 585, 2 (c\&s); T. zonatus, UFRJ 1136, 17, UFRJ 4549, 5 (c\&s), UFRJ 5321, UFRJ 5639, 2 (c\&s). Incertae sedis: Ituglanis parahybae, UFRJ 0702, 3, UFRJ 1103, 1 (c\&s); Scleronema sp., UFRJ 4185, 27, UFRJ 5826, 2 (c\&s). Sarcoglanidinae: Microcambeva ribeirae, MZUSP 78617, 4, MZUSP 68169, 3 (c\&s).

\section{Acknowledgements}

Special thanks to Henrique Jabor, who played a fundamental role during collection of the new species. We are grateful to ACSI/NSF Project (All Catfish Species Inventory/ National Science Foundation, NSF DEB-0315963) for funding the field expeditions. This study was supported by $\mathrm{CNPq}$ (Conselho Nacional de Desenvolvimento Científico e Tecnológico - Ministério de Ciências e Tecnologia). Collections were made under permit 072/2006 - DIFAP/IBAMA.

\section{Literature Cited}

Alencar, A. R. \& W. J. E. M. Costa. 2006. Trichomycterus pauciradiatus, a new catfish species from upper rio Paraná basin, southeastern Brazil (Siluriformes: Trichomycteridae). Zootaxa, 1269: 43-49.

Arratia, G. 1998. Silvinichthys, a new genus of trichomycterid catfishes from the Argentinian Andes, with redescription of Trichomycterus nigricans. Ichthyological Exploration of
Freshwaters, 9: 347-370.

Bizerril, C. R. S. F. \& P. B. S. Primo. 2001. Peixes de Águas Interiores do Estado do Rio de Janeiro. Rio de Janeiro: FEMAR SEMADS. $417 \mathrm{p}$.

Barbosa, M. A. \& W. J. E. M. Costa. 2003. Validade, relações filogenéticas e redescrição de Eremophilus candidus Ribeiro, 1949 (Teleostei, Siluriformes, Trichomycteridae). Arquivos do Museu Nacional, 61(3): 179-188.

Bockmann F. A., L. Casatti \& M. C. C. de Pinna. 2004. A new species of trichomycterid catfish from the Rio Paranapanema basin, southeastern Brazil (Teleostei: Siluriformes), with comments on the phylogeny of the family. Ichthyological Exploration of Freshwaters, 15: 225-242.

Bockmann, F. A. \& I. Sazima. 2004. Trichomycterus maracaya, a new catfish from the upper rio Paraná, southeastern Brazil (Siluriformes: Trichomycteridae), with notes on the T. brasiliensis species-complex. Neotropical Ichthyology, 2(2): 6174.

Castellanos-Morales, C. A. 2007. Trichomycterus santanderensis: A new species of troglomorphic catfish (Siluriformes, Trichomycteridae) from Colombia. Zootaxa, 1541: 49-55.

Castellanos-Morales, C. A. 2008. Trichomycterus uisae: a new species of hypogean catfish (Siluriformes:Trichomycteridae) from the northeastern Andean Cordillera of Colombia. Neotropical Ichthyology, 6(3): 307-314.

Costa, W. J. E. M. 1992. Description de huit nouvelles espèces du genre Trichomycterus (Siluriformes: Trichomycteridae), du Brésil oriental. Revue Française d'Aquariologie et Herpétologie, 18(4): 101-110.

Eigenmann, C.H. 1918. The Pygididae, a family of South American catfishes. Memoirs of the Carnegie Museum, 7: 259-398.

Fernández, L. \& R. Q. Chuquihuamaní. 2007. A new species of Trichomycterus (Siluriformes: Trichomycteridae) from the Andean Cordillera of Perú, with comments on relationships within the genus. Zootaxa, 1545: 49-57.

Fernández, L. \& G. Miranda. 2007. A catfish of the genus Trichomycterus from a thermal stream in southern South America (Teleostei, Siluriformes, Trichomycteridae), with comments on relationships within the genus. Journal of Fish Biology, 71: 1303-1316.

Fernández, L. \& K. Osinaga. 2006. A new Trichomycterus (Siluriformes: Trichomycteridae) from Aguarague National Park of the Bolivian preandean region, with comments on relationships within the genus. Environmental Biology of Fishes, 75: 385393.

Fernández, L. \& S. A. Schaefer. 2005. New Trichomycterus (Siluriformes, Trichomycteridae) from an offshore island of Colombia. Copeia, 2005(1): 68-76.

Miranda-Ribeiro, P. 1943. Dois novos Pigidídeos Brasileiros (PiscesPygidiidae). Boletim do Museu Nacional do Rio de Janeiro, 9: $1-3$.

de Pinna, M. C. C. 1989. A new Sarcoglanidine catfish, phylogeny of its subfamily, and an appraisal of the phyletic status of the Trichomycterinae (Teleostei, Trichomycteridae). American Museum Novitates, 2950: 1-39.

de Pinna, M. C. C. 1992. Trichomycterus castroi, a new species of trichomycterid catfish from the Rio Iguaçu of Southeastern Brazil (Teleostei: Siluriformes). Ichthyological Exploration of Freshwaters, 3: 89-95. 
de Pinna, M. C. C. 1998. Phylogenetic relationships of neotropical Siluriformes (Teleostei: Ostariophysi): historical overview and synthesis of hypotheses. Pp. 279-330. In: Malabarba, L. R., R. E. Reis, R. P. Vari, Z. M. S. Lucena \& C. A. S. Lucena (Eds.) Phylogeny and classification of neotropical fishes, Edipucrs, Porto Alegre. 603p.

de Pinna, M. C. C. \& W. B. Wosiacki. 2003. Family Trichomycteridae (pencil or parasitic catfishes). Pp. 270-290. In: Reis, R.E., S.O. Kullander \& C.J.Ferraris Jr. (Eds.), Check list of the freshwater fishes of South and Central America. EDIPUCRS, Porto Alegre, 729p.

Sarmento-Soares, L. M., R. F. Martins-Pinheiro, A. T. Aranda \& C. C. Chamon. 2005. Trichomycterus pradensis, a new catfish from southern Bahia coastal rivers, northeastern Brazil (Siluriformes: Trichomycteridae). Ichthyological Exploration of Freshwaters, 16(4): 289-302.

Taylor, W. R. \& G. C. Van Dyke. 1985. Revised procedures for staining and clearing small fishes and other vertebrates for bone and cartilage study. Cybium, 9(2): 107-109.

Wosiacki, W. B. 2005. A new species of Trichomycterus (Siluriformes: Trichomycteridae) from south Brazil and redescription of T. iheringi (Eigenmann). Zootaxa, 1040: 49-64.

Wosiacki, W. B. \& O. T. Oyakawa. 2005. Two new species of the catfish genus Trichomycterus (Siluriformes: Trichomycteridae) from the rio Ribeira de Iguape Basin, Southeastern Brazil. Neotropical Ichthyology, 3(4): 465-472.

Wosiacki, W. B. \& M. C. C. de Pinna. 2008a. Trichomycterus igobi, a new catfish species from the rio Iguaçu drainage: the largest head in Trichomycteridae (Siluriformes: Trichomycteridae). Neotropical Ichthyology, 6(1): 17-23.

Wosiacki, W. B. \& M. de Pinna. 2008b. A new species of the neotropical catfish genus Trichomycterus (Siluriformes: Trichomycteridae) representing a new body shape for the family. Copeia, 2008(2): 273-278.

Accepted September, 2008

Published September 30, 2008 